\title{
Ways to Support Student's Motivation in Academic Writing Course
}

Elina S. Chuikova*

Samara Branch of Moscow City Teachers' Training University 213 Novo-Vokzalnaya Str., Samara, 443084, Russia

Received 12.12.2014, received in revised form 10.02.2015 accepted 28.02.2015

The article focuses on methods of teaching academic writing in Russia. Intrinsic motivation is the key to effective foreign language acquisition. The author examines factors that make motivation to use English for academic purposes (EAP) wane. The researcher suggests different solutions in the area of writing for academic purposes. They all stand within the learner-centered approach, and they are aimed at humanising the process of teaching academic writing. Additionally, they link students' interests with the real demands of the Russian policy in higher education and science. A teacher may resort to various sources of motivation, both global and situational, or task oriented: social demands, "intellectual curiosity" (showing future perspectives), professional achievements, and genuine communication with the readers' feedback. The author concludes that intrinsic motivation creates a unique educational environment which contributes to easier perception of academic writing numerous conventions.

Keywords: motivation, academic writing, EAP, methods of teaching, learner-centered approach.

Research area: pedagogy.

\section{Introduction}

Academic writing fulfils one of the central roles in professional education. By writing, students learn general rules of communication, tendencies common for any speech mode in a professional context. They develop their skills and abilities of critical thinking, organising their ideas in a logical way, presenting the results of the research in accordance with the conventions of academic environment. The gained skills pertain to overall language competence.

Academic writing in a foreign language for EFL (English as a foreign language) teachers happens to be a more complicated phenomenon from the pedagogical viewpoint. Written norms and requirements to the written texts vary from culture to culture. The usage area of English for Academic Purposes (EAP) in the Englishspeaking country may differ considerably from that in other countries. My 10 year experience as a lecturer in Academic Writing in a Russian University has led me to the problem of motivation that primarily causes low efficiency of academic texts written by Russian-speaking students in English. This is further reflected in numerous lapses in style, vocabulary register, grammar structures and text genres. Similar correlation of low motivation and negatively predicted

(C) Siberian Federal University. All rights reserved

* Corresponding author E-mail address: chuikova_elina@mail.ru 
performance in writing is stated in academic context in other countries as well (Baaijen et al., 2014, Sanders-Reio et al., 2014). Writing beliefs vary and interact influencing text quality.

\section{Statement of the Problem}

Making a longitudinal research on this field I have distinguished the following reasons of low motivation in L2 (second language ) academic writing by language students in Russia.

1. To begin with, language teachers are not prepared to explain the strategic need in EAP, and writing skills in particular. As a result a limited number of EFL students realise their need in academic writing. Though a new generation of teachers in the Post-Soviet period started to perceive writing as an equal means of communication, English for academic purposes was not required. Until recently it has been required to only a small extent.

Nowadays the situation has changed. English has become the main language for international academic discourse. However, according to Web of Science (WoS) - the most comprehensive global database of publications in scientific journals, provided by Thomson Reuters - Russia is currently in the 13th place by number of publications and in the 22nd place by their citations (Baranov).

The Presidential Decree "On measures to implement the state policy in the field of education and science" was signed in (May 2012). Among other things, the Decree set the task of increasing the proportion of publications by Russian researchers in the total number of publications in the international scientific journals indexed in the WEB of Science database up to $2.44 \%$ by 2015 . To achieve the above target is one of the urgent tasks that institutions of higher education and scientific institutions face.

2. Language students tend to confuse a good command of general English with good skills in EAP. They suppose that the ability to write in English automatically enables them to write essays, summaries, reports etc. Fortunately, they become easily aware of the fact that every type of writing is characterized by its own text genres. This is equally concerned with linguistic and nonlinguistic students (Sidorenko, 2011). As soon as students get acquainted with new study genres and criteria of their assessment, they realize the necessity to know genre conventions.

3. EFL students also tend to confuse the written norms of the academic texts in the Russian language with those in the English language. They genuinely believe that one can easily transfer writing skills without taking into consideration the fact that writing skills are culturally determined. The ideas of contrastive rhetoric are being introduced into the studying process as the results of the 12-year monitoring process through the all-Russia State Exam. The state research (Foreign Languages, p. 397) of the written part highlighted obvious interference of the native language background with text production in a foreign language.

4. The subject itself is challenging. Academic writing requires knowledge of strict regulations. They concern style of the language, structuring the ideas, conventions in the way a writer quotes, organises bibliography, presents the final draft etc. These limitations may reduce any joy of learning. Fortunately, creative teachers introduce elements of creative writing into a serious academic course, since they know that creative writing helps to improve expository writing as well. In fact, development of learners' individual voice makes their factual writing more genuinely expressive (Maley, 2012).

5. Additionally, the tasks aimed at training students to follow academic conventions (models) may be of little motivation (Paltridge, 2014). On the contrary, genuine writing is creative by nature. A teacher must vary the tasks, forms of 
their organization and assessment to humanise the process of teaching academic writing.

In this article I will look at the strategies and practical techniques used in the course of Academic Writing in English. I have found them useful for improving my students' motivation to writing and developing culture of communication in academic environment on the whole.

\section{Theoretical Framework}

The better way to start literature review is to compare understanding of "academic writing" and its specifics in the English-speaking and Russian sources. I am deeply convinced that writing is 'cultural phenomenon'. Surprisingly, teaching practice leads to understanding that the ideas of contrastive rhetoric (about cultural determination of speech production) should be employed not only in strategies of writing but in the sphere of academic language application as well.

David Crystal (2008) defines academic language as the language of academic prose. According to R.R. Jordan, 'the specific types of academic writing include essays, research reports and articles, case studies, surveys, dissertations, and examination papers' (1999).

Other sources claim that 'academic writing is the way through which university students communicate with their lecturers or which academicians communicate with their colleagues' (Saadet Pınar Çalgan and Zeynep Cansever, 2011).

In the English-Russian Terminology Dictionary of Teaching Foreign Languages Methodology by Kolesnikova I.L. \& Dolgina O.A. (2008) "academic writing" is synonymous to "study writing", and thus it serves the study purposes in high institutions. It is mostly meant for the development of critical thinking. Other Russian researches in academic discourse also tend to define academic prose mostly as the result of studying at high institutions and partially as the result of research done by young scholars who are in the process of developing their own style of science writing (Smirnova, 2000, Chernyavskaya, 2007).

Academic writing rests on 'externally imposed rules and conventions'. (Maley,2012) They primarily concern grammar and style of writing as academic prose is one of the least situation-dependent written genres. Moreover, while writing in a foreign language we are expected to follow these rules: 'Unwritten rules of English academic rhetoric are unconsciously expected within the English linguistic community' (Rheid, 2010).

Thus, academic writing is a specific type of writing used in academic goals by students and starting scholars who are in the process of developing their own style of science writing. It is characterised by its own text genre repertoire, written rules of grammar, vocabulary and style usage and by unwritten rules of English academic rhetoric.

\section{Methods}

'The hegemony of English in academic world' (Rheid, 2010:7) presupposes vital necessity to acquire actively EAP in all its forms. Both groups of students - those who plan to write science and those who plan to teach language - need academic writing norms to follow: to produce new knowledge, to reproduce somebody's ideas, to train other people in academic writing, to assess their achievements (Maclellan, 2008, Noteborn et al., 2014, Parker, 2010). Teaching academic writing provides opportunities both for the development of essential professional (academic) skills and transferable at the labour market skills. Thus, teaching in an academic context is practice-oriented in a number of ways.

Seeing the huge social demand in qualified teachers of academic writing, University 
English teachers find a problem with students passively attending the lectures. Every country has its own educational policy. Subsequently, motivation problem should be solved within the frames of the state official policy in education. The outstanding Russian contemporary Professors of Pedagogy Sh. Amonashvily, V. Davydov, V.F.Shatalov, V.A. Sukhomlinsky and B.I. Vershinin, A. Leontyev, I. Zimnyaya, E. Passov, Y. Polat develop the ideas of Humanistic Pedagogy that is aimed at a critically thinking and creative student (Polat E.S. \& M.U. Bukharkina, 2007, Postniko S.N. \& A.V. Andrienko, 2013).

The leading ideas of Humane Pedagogy are reflected in Learner-centered approach as well as in Task-based approach to learning. Modern teaching technologies - that suit the Russian educational paradigm - focus on learnercentered, cooperative and collaborative learning, on teachers-facilitators and actively participated students.

Learner-centered approach includes:

- techniques that focus on learners' needs and interests,

- techniques that give some control to the student (for example, in group work)

- techniques that allow for student creativity,

- techniques that enhance a student's sense of progress,

- a facilitator who creates the learnerfriendly environment and cherishes students' individual abilities.

To some extent the world practice in teaching writing implements ideas of learnercentered approach focusing on process writing. However, labour market demands require reasonable combination of genre-based approach (in which a focus is on the academic genres conventions) with process writing (in which a focus is on the creation process, e.g. on generating ideas techniques, on individual learner's writing strategies). A flexible approach enables graduates to gain more practical skills that may transfer in various sociocultural contexts of writing (Haneda, 2014, Noteborn et al., 2014, Paltridge 2014).

In Russia, contrarily, we adopted genrebased approach in EFL writing, first. As a result we need to introduce more elements of individual approach with the focus on the process of writing to balance the 'mechanic' copying models methodology. We are presently shifting to more communicative and motivating process of teaching academic writing.

\section{Findings}

To be intrinsically oriented the technique shouldnotbepresumablyinnovativebutreasonably challenging and (what is more important for student audience) professionally-oriented. They need clear ideas of their professional perspectives, of their personal goals, of their own progress on the way to these goals. Seeing correlation of professional and personal goals means helps to satisfy the highest need - self-actualization. If we provide our students with long-term goals by means of Academic Writing course, then gaining academic writing norms (culture) may become highly-motivated.

Teaching Academic writing in Russia has its own specifics:

- teaching Academic Writing to the students that have had no academic background (non-academic students);

- teaching the subject which has application different from that in English-speaking countries

Keeping in mind these 2 cornerstones I usually employ problem solving strategy to motivate students.

Intrinsic motivation is impossible without understanding the necessity of the subject a 
person studies. To prevent the possible 'conflict' of teacher's and students' interests I usually start a series of seminars with 2 essential things.

First, it seems reasonable to open a seminar with the up-to-date information on the subject. I share with my students the results of the educational projects dealing with academic writing skills.

e.g. Have a look at the 'Global Science' Project held by Russian International Affairs Council (http://russiancouncil.ru/projects/ project/?PROJECT_ID_4=13) and scan the material of Natalie Reid's lecture on academic writing organised by Russian International Affairs Council in April 2013(http:// russiancouncil.ru/inner/?id_4=1686\#top). Think of the possible reasons for the interest to academic writing skills in English. Why is the topic being discussed in Russia at the Ministerial level? Is the information related to your future profession? Do you need any of the competencies discussed? In what way?

Second, I provide students with the model essay.

e.g. Task: Imagine that you are a university teacher reading the essay of one of your students. Think of the possible comment you may give on its content, organisation, style, presentation manner. While reading find the examples that may illustrate your comments.

The well-thought support makes the challenge reasonable though the students may look at an academic text from a teacher's perspective for the first time. The aim of the activity is to reveal the gap between the amount of knowledge students possess at the moment and that they need in future to be considered qualified specialists. Suggestive questions assist students in their way to awareness of criteria used to assess this type of work. Gradually they learn the main terms/terminology. Additionally,
I immediately introduce the idea that Academic Writing course is not totally about writing. It is based and assessed with reading-to-write tasks alongside with writing-only tasks (Gebril, 2010).

At the end of the course they write a report on taking academic writing course to reflect on their own history as a writer. It is a rare opportunity to understand how they got to where they are today: an informed reader of other peoples' writing.

Additionally, a teacher may resort to other types of classroom motivation. There may be distinguished situational and task oriented motivation along the "global" one.

Professional achievements are not the only factor that fosters students' motivation. Students' self-confidence may also wake "intellectual curiosity" (Klein and Unsworth, 2014). In case students see the positive dynamics while comparing their results from draft to draft, getting supportive written feedback (that of a teacher or of their peers), writing a report on their course results or 'A Writing Self-Biography', they develop motivation to learn further. Immediate success moves learners in their studies (Cumming, 2009, Duijnhouwer et al., 2012, Ferris, 2010, Gast et al., 2012).

Ensure that the students' work is 'published' in some way. This could be by simply keeping a large notice-board for displaying the students' work. Other ways would include giving students a project for publishing work in a class website (blog) where work can be published. Performances, where students read or perform their work for other groups or even the whole university, are another way of making public what they have done. With their permission we publish their works as models for analysis in textbooks in our department.

Encourage students to discuss their work together in a frank but friendly manner. 'We get 
good ideas by bouncing them off other people. Help them establish an atmosphere where criticism is possible without causing offence' (Maley, 2012). Additionally, collaborative work will enrich their communication experience (Haneda, 2014) and provide them with a new angle of view on their works, as teachers and students tend to focus on different aspects of texts (Bodwell, 2004). Research of peer correction activities highlights the fact that anxiety about being criticised is not significant after all (Sanders-Reio et al., 2014). However, peer-editing as any social activity should be taught and guided in the beginning to be more efficient and constructive.

Additionally, there is an effective tendency to employ social motivation in Academic Writing classes through introduction students into contrastive rhetoric ideas (Paltridge, 2014, Reid, 2010). Feeling proud of their national way of thinking and, consequently, writing, learners are more eager to further compare and memorise conventions of academic language in other cultures. Through the perspective of contrastive rhetoric, we have been organising the course of Academic writing for 10 years. Today it has been formed into the course titled "Academic Writing: English Phenomenon in Russian Interpretation".

\section{Discussion and Conclusion}

Implementing the ideas of learner-centered approach in teaching academic writing I would recommend the following fruitful strategies that promote intrinsic motives:
- design the whole course and its elements (lectures, seminars, tasks) in a problem solving way;

- let theory come first to support practice of 'non-academic' students;

- meet the particular age group needs explain clearly professional perspectives for graduate students acquiring academic writing;

- turn to the weight of the English-speaking specialists in academic writing when possible;

- provide students with the opportunity to be "published" or to be read: real communication motivates better than lecturing;

- employ peer-editing as an act of communication, guide it to make reflection on the work more constructive;

- get students acquainted with ideas of contrastive rhetoric.

Intrinsically oriented techniques may foster different motives (professional, social and personal) working at different levels (global and situational).

Motivation is vital for successful L2 acquisition. Russia has a unique educational environment in which to learn academic English is now regarded as an essential step in the achievement of higher levels of proficiency. However, teaching English for academic purposes lacks far behind. It requires considerable changes in methods of teaching and adaptation of textbooks to the Russian writers' needs, and fostering various types of students' learning motives.

\section{References}

1. Baaijen, V.M, Galbraith, D., de Glopper, K. (2014) Effects of writing beliefs and planning on writing performance Learning and Instruction, Volume 33, pp. 81-91. doi:10.1016/j. learninstruc.2014.04.001

2. Baranov, I. Publish or Perish? Available at: http://russiancouncil.ru/en/inner/?id_4=775\#top (accessed 10 May 2014). 
3. Bodwell, M.B. (2004) "Now what does that mean, "first draft'?": responding to text in an adult literacy class. Linguistics and Education, Volume 15, Issues 1-2, pp. 59-79. doi:10.1016/j. linged.2004.10.001

4. Chernyavskaya, V.E. Interpretaziya Nauchnogo Teksta (Text Interpretation in Science). Moscow: LKI, 2007. 127 p.

5. Crystal, D. (Ed.) (2009). The Cambridge Encyclopedia of the English Language. Cambridge University Press.

6. Cumming, A. (2009). Assessing academic writing in foreign and second languages. Language Teaching, 42, pp. 95-107. doi:10.1017/S0261444808005430

7. Duijnhouwer, H., Prins, F. J., Stokking K. M. (2012) Feedback providing improvement strategies and reflection on feedback use: Effects on students' writing motivation, process, and performance. Learning and Instruction, Volume 22, Issue 3, June 2012, pp.171-184. doi: 10.1016/j. learninstruc.2011.10.003

8. Ferris, D.R. (2010). Second Language Writing Research and Written Corrective Feedback in SLA. Studies in Second Language Acquisition, 32, pp.181-201.doi:10.1017/S0272263109990490

9. Gast, A., Gawronski, B., De Houwer, J. (2012) Evaluative conditioning: Recent developments and future directions. Learning and Motivation, Volume 43, Issue 3, pp. 79-88. doi:10.1016/j. lmot.2012.06.004

10. Gebril, A. (2010) Bringing reading-to-write and writing-only assessment tasks together: A generalizability analysis. Assessing Writing, Volume 15, Issue 2, pp. 100-117. doi: 10.1016/j. asw.2010.05.002

11. Haneda, M. (2014) From academic language to academic communication: Building on English learners' resources. Linguistics and Education, Volume 26, pp.126-135. doi:10.1016/j. linged.2014.01.004

12. Inostrannye Iazyki (Foreign Languages) Available at: http://fipi.ru/view/sections/138/ docs/318.html (accessed 10 May 2014).

13. Jordan, R. R. (Ed.) (1999) Academic Writing Course. Pearson Education Ltd. PP. 146.

14. Klein, P.D., Unsworth, L. (2014) The logogenesis of writing to learn: A systemic functional perspective. Linguistics and Education, Volume 26, pp.1-17. doi:10.1016/j.linged.2013.12.003

15. Kolesnikova, I.L. \& Dolgina, O.A Anglo-Russkii terminologicheskii spravochnik po metodike prepodavaniya inostrannykh yazykov (The English-Russian Terminology Dictionary of Teaching Foreign Languages Methodology). St. Petersburg, Cambridge University Press, 2001. P. 224.

16. Maclellan, E. (2008) Pedagogical literacy: What it means and what it allows. Teaching and Teacher Education, Volume 24, Issue 8, pp. 1986-1992. doi: 10.1016/j.tate.2008.05.009

17. Maley, A. Creative Writing for Students and Teachers. Humanising Language Teaching. Issue 3; June 2012. Available at: http://www.hltmag.co.uk/jun12/mart01.htm (accessed 10 May 2014)

18. Noteborn, G., Hebert, A.D., Carbonell, K.B., Gijselaers, W. (2014) Essential knowledge for academic performance: Educating in the virtual world to promote active learning Teaching and Teacher Education, Volume 37, pp. 217-234. doi: 10.1016/j.tate.2013.10.008

19. Paltridge, B. (2014) Genre and second-language academic writing. Language Teaching, Volume 47, Issue 03, pp 303-318. doi: 10.1017/S0261444814000068

$$
-978-
$$


20. Parker, D.C. (2010) Writing and becoming [a teacher]: Teacher candidates' literacy narratives over four years. Teaching and Teacher Education, Volume 26, Issue 6, pp. 1249-1260. doi: 10.1016/j. tate.2010.03.002

21. Polat, E.S. \& Bukharkina, M.U. Sovremennye pedagogicheskie I informatsionnye tekhnologii $v$ sisteme obrazovaniya (Modern Pedagogic and Information Technologies in the system of Education). Moscow: Academia, 2007.

22. Reid, Natalie (2010). Getting Published in international Journals: Writing Strategies for European Social scientists. Norway. Norwegian Social Research.

23. Romova, Z., Andrew, M. (2011) Teaching and assessing academic writing via the portfolio: Benefits for learners of English as an additional language. Assessing Writing, Volume 16, Issue 2, pp. 111-122. doi:10.1016/j.asw.2011.02.005

24. Saadet Pınar Çalgan \& Zeynep Cansever. Academic Writing With 'Non' Academic Learners. Humanising Language Teaching. Issue 6; December 2011. Available at: http:/www.hltmag.co.uk/ dec11/sart04.htm (accessed 10 May 2014)

25. Sanders-Reio, J., Alexander, P.A., Reio Jr. T. G., Newman, I. (2014) Do Students' Beliefs about Writing Relate to Their Writing Self-Efficacy, Apprehension, and Performance? Learning and Instruction, Volume 33, pp. 1-11. doi: 10.1016/j.learninstruc.2014.02.001

26. Sidorenko, T.V. (2011) K Voprosu Ob Obuchenii Inoyazychnoi Pis'mennoi Kommunikatsii Studentov Neyazykovogo Vuza (Teaching Academic Writing to Non-Linguistic Students). Vestnik of Chelyabinsk State Pedagogical. Issue 10, pp. 133-140.

27. Smirnova, N.I. (2000) Stanovlenie Akademicheskogo Yazyka v Sotsiume. Science Notes: Important Issues of Linguistics and Linguodidactics. Issue 2(5). Ul'anovsk: UlGU, pp. 46-53.

28. Ukaz o merakh po realizatsii gosudarstvennoy politiki $v$ oblasti obrazovaniia $i$ nauki (Presidential Decree "On measures to implement the state policy in the field of education and science") Available at: http://kremlin.ru/acts/15236 (accessed 10 May 2014). 


\title{
Мотивирующие формы обучения \\ академической письменной речи
}

\author{
Э.С. Чуйкова \\ Самарский филиал Московского городского \\ педагогического университета \\ Россия, 443084, Самара, ул. НовоВокзальная, 213
}

Статья посвящена методике обучения академическому письму на английском языке в российских вузах. Основным источником эффективного овладения иностранным языком является внутренняя мотивация. Целесообразно рассмотреть факторы, которые снижают или препятствуют формированию внутренней мотивации к овладению английским в академических иелях. Выделение таких факторов в статье позволило разработать ряд решений по их минимизации. Все рекомендации разработаны в рамках личностно-ориентированного, гуманистического подхода к обучению. Преимуществом данных решений является то, что они позволяют объединить внутренние индивидуальные потребности учащихся с внешними требованиями, которые предъявляются к выпускнику вуза в современной России. Так, преподаватель может обратиться к различным источникам мотивации: иироким и узким социиальо-профессиональным мотивам, к мотивам профессионального самообразования и профессионального сотрудничества. Это возможно благодаря проблемному методу обучения, просветительской деятельности, организации саморефлексии и самооценки результатов обучения студентов, публикации студенческих письменных работ, включению социокультурньх параллелей в обучение.

Ключевые слова: мотивация, академическое письмо, английский для академических изелей, методика преподавания.

Научная специальность: 13.00.00 - педагогические науки. 